\title{
Sphere-Rod Morphogenesis of Escherichia coli
}

\author{
By E. W. GOODELL AND U. SCHWARZ \\ Friedrich-Miescher-Laboratorium der Max-Planck-Gesellschaft, 74 Tübingen, Germany
}

(Received 10 June 1974; revised 4 September 1974)

\begin{abstract}
SUMMARY
The morphogenetic capacity of $E$. coli was studied by converting the rodshaped cells into spheres and then determining whether these spheres could revert to rods. The morphogenesis of cells was followed by immobilizing them in a viscous Methocel-containing medium. Two different types of spheres were prepared: cells which retained a mechanically intact sacculus, and osmotically sensitive sphaeroplasts lacking a sacculus. The sphaeroplasts were not able to revert to rods although they were able to synthesize a new sacculus. In contrast, spheres which had retained an intact sacculus were able to reshape themselves into rods. They were also able to form new ends at (or near) the sites of the ends on the original rods.
\end{abstract}

\section{INTRODUCTION}

Regeneration experiments have been one of the classical approaches used to study the control of morphogenesis in multicellular eukaryotes. Some of these organisms have the capacity to form a complete organism from a small piece of body tissue. Extensive regeneration of this sort is often polarized; the anterior end of the regenerating organism is formed at the anterior end of the fragment. In single-celled prokaryotes such regeneration experiments are not possible since small sections cut from them are not viable. However, it is possible to study the morphogenetic capacity of these cells by artificially altering their shape and then measuring their capacity to return to the original shape: one can convert Escherichia coli rods into spheres and determine whether they can reshape themselves into rods. One can also determine whether the polarity of the original rods is retained, by investigating whether new ends are formed at the sites on the envelope where the original ends were.

The growth of spherical $E$. coli was first described by Lederberg (1956). He reported that the spheres themselves were not able to revert to rods; only by forming rod-shaped outgrowths were they occasionally able to produce rods. In these experiments the formation of spheres involved a considerable alteration in wall structure: the spheres were sphaeroplasts formed by disruption of the sacculus, the substructure of the envelope which gives it its mechanical stability and maintains cell shape. Therefore, it remained open whether loss of the sacculus damaged the cell and affected its morphogenetic capacity, or whether spherical $E$. coli were inherently unable to revert to rods.

In this study we have made use of the fact that it is possible to form spherical $E$. coli which retain an intact sacculus with the aid of a new penicillin derivative, penicillin FL-I060 (Lund \& Tybring, 1972; Greenwood \& O'Grady, 1973). Morphogenetic mutants are also available which become spheres with an intact sacculus after a temperature shift (Henning et al. 1972). The growth of cells was followed in Methocel medium (Lin, Hirota \& Jacob, 197I). In this viscous liquid they remain in place and do not loose their original orientation. Thus it was possible to determine whether polarity was retained during rod-sphere-rod 
morphogenesis. We found that cells which retained their sacculus were able to reshape themselves into rods, and that the areas of the envelope which had been the ends of the original rods again became ends in the newly formed rods.

\section{METHODS}

Strains and media. Escherichia coli $\mathrm{w} 7$ (Ryter, Hirota \& Schwarz, 1973), requiring meso2,6-diaminopimelic acid (DPM) and lysine, was used in most experiments. The temperaturesensitive morphological mutant Lss I2 (Henning et al. 1972), derived from w945T3282 (F-, thi, leu, trp, lac, gal, his, thy, dpm, lys, thr), was obtained from Dr U. Henning. Strain W7 was grown in $\mathrm{MC}$, a minimal citrate medium (Vogel \& Bonner, 1956) supplemented with glucose $(2 \mathrm{mg} / \mathrm{ml})$, DPM $(20 \mu \mathrm{g} / \mathrm{ml})$ and Casamino acids $(2 \mathrm{mg} / \mathrm{ml}$; Difco). To form sphaeroplasts from $\mathrm{w}_{7}$ by DPM starvation, the cells were grown in $\mathrm{MC2}$, a minimal medium containing glucose $(2 \mathrm{mg} / \mathrm{ml})$, Casamino acids $(2 \mathrm{mg} / \mathrm{ml})$, sucrose ( $12 \%$, W/v) and $0 . \mathrm{I} \mathrm{M-}$ $\mathrm{MgSO}_{4}$. Lss $\mathrm{I} 2$ was grown in complete medium (antibiotic medium No. 3, Difco) supplemented with thymine $(5 \mu \mathrm{g} / \mathrm{ml}), \mathrm{DPM}(20 \mu \mathrm{g} / \mathrm{ml}), \mathrm{MgSO}_{4}(\mathrm{O} \cdot \mathrm{I} \mathrm{M})$ and sucrose (I $\left.2 \%, \mathrm{w} / \mathrm{v}\right)$. Unless otherwise stated, the bacteria were grown at $30{ }^{\circ} \mathrm{C}$. Penicillin FL- $1060 \cdot \mathrm{HCl} \cdot 2 \mathrm{H}_{2} \mathrm{O}$ (a gift from Leo Pharmaceutical Products Ltd, Ballerup, Denmark) was used at a concentration of $\mathrm{I} \mu \mathrm{g} / \mathrm{ml}$.

Cultivation of $\mathrm{w} 7$ in Methocel media. Cells were grown in either $\mathrm{MC}$ or $\mathrm{MC} 2$ containing $3 \%$ (w/v) Methocel (Roth Laborchemikalien, Karlsruhe, Germany) and the medium was spread on glass slides as described by Lin et al. (197I). Instead of paraffin oil, a cover slip was placed over the Methocel. A thin strip of stopcock grease around the edge of the cover slip prevented it from touching the Methocel and served as a seal. To prevent fogging, the cover slip was coated with a $0.1 \%$ solution of Triton X-Ioo (Serva).

Penicillinase (Calbiochem, B grade), if needed, was added to the Methocel medium on the glass slides with a small wire loop. The penicillinase was dissolved in MCI (I80000 units $/ \mathrm{ml}$ ) containing $0.013 \%$ Triton X-100 to reduce the surface tension. Fifteen minutes before the addition of the penicillinase, the slide and the penicillinase were placed at $4{ }^{\circ} \mathrm{C}$. At this temperature the viscosity of the Methocel-containing medium was higher and the cells were held more firmly in place while the penicillinase solution was added. The wire loop $(7 \mathrm{~mm}$ diam, made from $0.01 \mathrm{~mm}$ diam wire) was dipped into the penicillinase solution, causing a film to form across the loop. Excess solution was removed from the loop and it was then touched to the Methocel medium. A ring of excess solution often remained on the medium where the wire itself had touched it; this was carefully removed. The slide was left at $4{ }^{\circ} \mathrm{C}$ for another $15 \mathrm{~min}$ and then returned to $30{ }^{\circ} \mathrm{C}$.

DPM was applied to the Methocel medium in the same manner. The DPM $(20 \mu \mathrm{g} / \mathrm{ml})$ was dissolved in MC2 medium containing $0.013 \%$ Triton X-100.

Cultivation of Lss 12 in Methocel medium. The cells were grown in complete medium containing $0.7 \%$ Methocel. (The $3 \%$ Methocel medium used above was too viscous at $42{ }^{\circ} \mathrm{C}$ to allow the cells to grow in chains.) The medium was placed between a glass slide and a cover slip and thinned to a thickness of $\mathrm{I}$ to $2 \mu \mathrm{m}$.

Photography. Phase contrast micrographs were taken with a Wild compound microscope equipped with an automatic camera. To measure cell dimensions and orientation, the images were projected onto a screen (total magnification $\times 4000$ ).

Preparation of sacculi. Sacculi were isolated by boiling the cells in $4 \%(\mathrm{w} / \mathrm{v})$ sodium dodecyl sulphate for I 5 min (Ryter et al. 1973) and then treating with $\alpha$-amylase (Merck) to remove glycogen trapped inside the sacculi (Leutgeb \& Weidel, r963). The sacculi were 


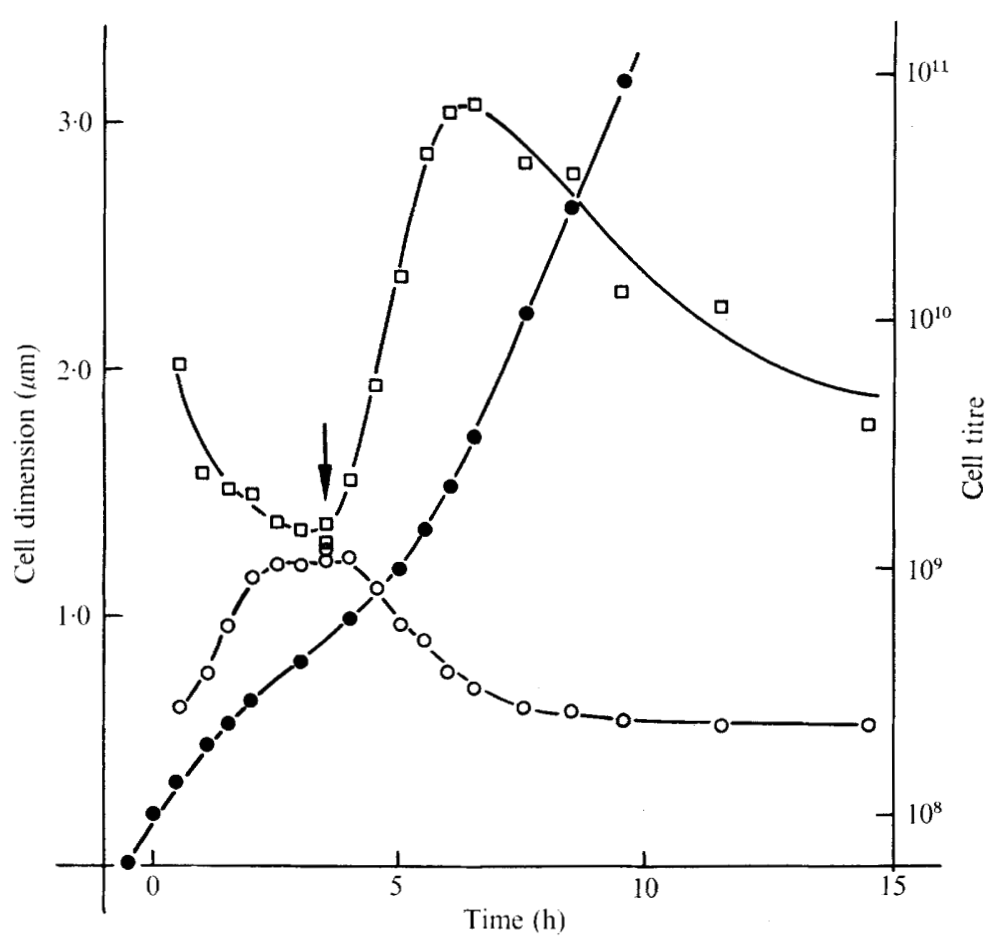

Fig. I. Rod-sphere-rod morphogenesis of $E$. coli in liquid medium. Penicillin FL-Io6o was added to an exponentially growing culture of $E$. coli w7. After the cells had become spherical ( $3.5 \mathrm{~h}$; arrow), they were washed twice and inoculated into a penicillin-free medium. Samples were periodically removed and the bacteria photographed. From the photographs the length $(\square)$ and width $(\bigcirc)$ of 100 bacteria from each sample were measured. Bacteria in the process of division were not measured. Cell titre (O) was measured with a Coulter counter. To allow continued exponential growth, the culture was diluted tenfold after $3 \cdot 5,7 \cdot 5,9 \cdot 5$ and II $5 \mathrm{~h}$.

resuspended in $0.1 \%$ sodium dodecyl sulfate (Ryter et al. I973) and prepared for electron microscopy as described by Kellenberger \& Arber (1957).

\section{RESULTS}

Formation of spheres with penicillin FL-1060

In minimal medium, $E$. coli w7 were rods with a diameter of $0.6 \mu \mathrm{m}$ and an average length of $2.0 \mu \mathrm{m}$. When penicillin FL-1060 was added to the medium, they gradually lost their rod form (Fig. I). The length decreased and the width increased, until after 3 to $4 \mathrm{~h}$ they were spherical with a diameter of $\mathrm{x} \cdot 2 \mu \mathrm{m}$. They continued to divide both during (Fig. I) and after this rod-sphere transition.

The spheres did not require osmotic protection, and physically intact sacculi could be isolated from them (Fig. 2). In general, penicillins cause breakdown of the sacculus; they inhibit the synthesis of murein [the polymer from which the sacculus is made (Weidel \& Pelzer, 1964)], specifically the formation of peptide cross-links in the murein (Strominger et al. 1971). This is not so with penicillin FL-1060 (Park \& Burman, 1973). Under the conditions used in our study ( $\mathrm{I} \mu \mathrm{g}$ penicillin/ml minimal medium), penicillin FL-I060 did not 


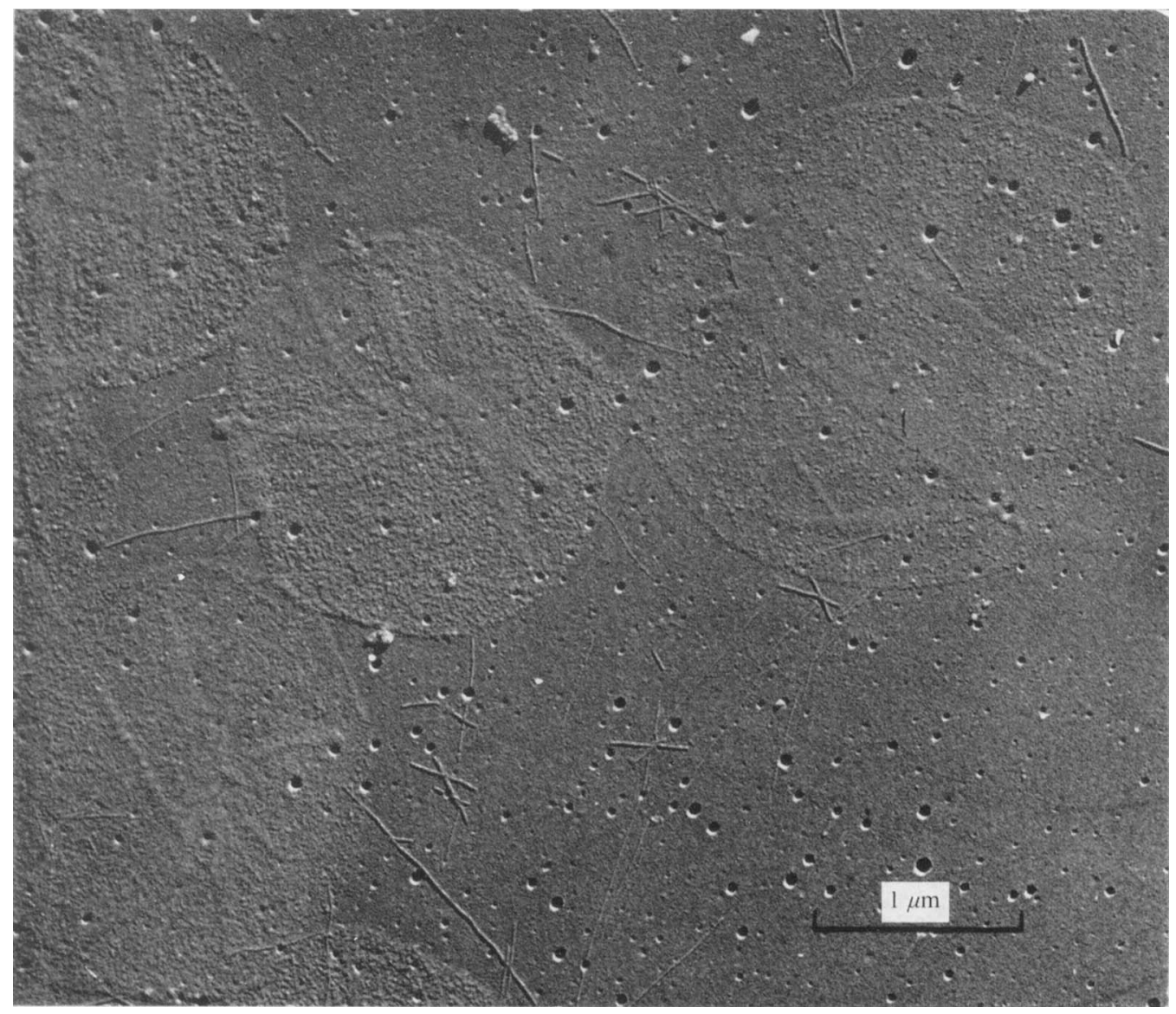

Fig. 2. Sacculi from penicillin FL-I060-treated cells. Escherichia coli w7 were grown for $4 \mathrm{~h}$ in medium containing penicillin FL-I060. The sacculi were isolated by boiling the cells for $15 \mathrm{~min}$ in $4 \%$ sodium dodecyl sulphate (Ryter et al. I973).

affect the degree of peptide cross-linking, nor did it inhibit the rate of murein synthesis (A. Asmus and U. Schwarz, unpublished).

\section{Sphere-rod morphogenesis after removal of penicillin $F L-1060$}

After $3.5 \mathrm{~h}$ growth in penicillin FL-I060, E. coli w7 had lost their original shape and dimensions. Electron micrographs of these cells, or of isolated sacculi (Fig. 2), indicated that they were almost perfectly spherical.

To determine if these cells could reshape themselves into rods with the proper dimensions, they were washed twice in minimal medium and inoculated into either fresh penicillin-free liquid medium (Fig. I), or into solid Methocel-containing medium (Fig. 3) to follow the growth of single cells. In both media cells transformed themselves into relatively straight rods with differentiated ends and middles within one to two generations. Many of the rods were bent, but the angle of the bend was usually small; of 850 cells measured (liquid medium) 90 min after removal of the penicillin, $80 \%$ had a bend of less than $30^{\circ}$. (Untreated $\mathrm{w} 7$ had no detectable bend.) A small proportion ( $7 \%$ ) of the cells were $Y$-shaped, with three ends.

The cells also reduced their diameter (Figs. I and 3). In liquid medium they started to 




Fig. 3. Sphere-rod morphogenesis in solid Methocel medium after removal of penicillin FL-Io6o. Escherichia coli w7 were grown for $3.5 \mathrm{~h}$ in penicillin FL-I060-containing medium and then transferred to Methocel medium which lacked penicillin. Pictures were taken after $(a) \mathrm{I} h,(b) 2 \mathrm{~h},(c) 2 \cdot 75 \mathrm{~h}$, (d) $3.25 \mathrm{~h}$ and (e) $3.75 \mathrm{~h}$.

reduce their diameter within 30 min of the removal of penicillin FL-I060. They readjusted their diameter to that of the untreated rods; thereafter their diameter remained constant (Fig. I). Changes in length were more complex; after 90 min many were longer than normal rods (Fig. I). These 'filaments' did not disappear from the medium until $6 \mathrm{~h}$ after removal of the penicillin.

Normally, rod-sphere-rod morphogenesis required several generations to complete (Fig. I). However, single cells in principle were able to undergo the complete rod-sphere-rod transition without dividing. This was shown by growing cells in Methocel medium and treating them with nalidixic acid $(50 \mu \mathrm{g} / \mathrm{ml})$ which inhibits DNA synthesis and cell division (Goss, Deitz, \& Cook, I964). They were able to form spheres and to revert to rods; they became long filaments. However, protein synthesis was apparently necessary. Spherical cells did not revert to rods when chloramphenicol (Ioo $\mu \mathrm{g} / \mathrm{ml}$ ) was added to the medium or when lysine was deleted from the medium (w7 is a lysine auxotroph).

\section{Polarity of end formation}

We attempted to determine whether the spheres were forming new ends at random sites on their surface or specifically at those sites which originally had been ends in the rods before penicillin treatment. To do this, the rod-sphere-rod morphogenesis of cells was followed in Methocel medium.

When normal E. coli are grown in Methocel medium, they form chains of cells aligned end to end; the long axis of each cell lies along the axis of the chain (Lin et al. 197I). If these cells are converted to spheres and then allowed to become rods again, they should re-form themselves into a chain of rods aligned end to end if they are able to re-form the ends of the original rods. If, however, the reverting cells formed ends at random sites on their surface, then the newly formed rods should not lie end to end, nor should the long axis of the rods lie along the chain axis.

During the complete rod-sphere-rod morphogenesis, the cells divided three or more times. The resulting chains were long and often became disorganized. To overcome this problem, the chain length was reduced to a minimum (i.e. to two cells). This was done by growing the cells for one $\mathrm{h}$ in liquid medium in the presence of penicillin FL-Io6o before transferring 

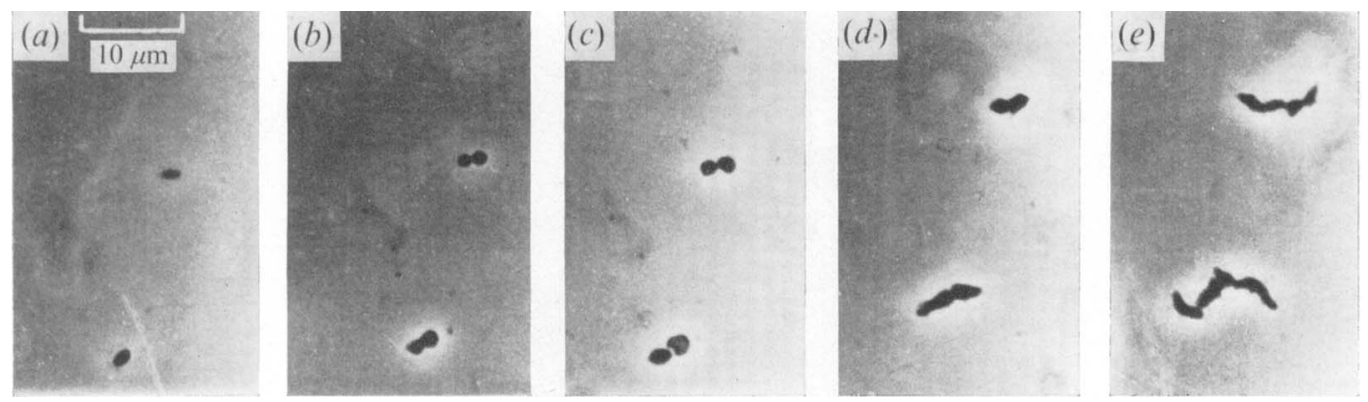

Fig. 4. Polarity of end formation. Escherichia coli w7 were grown for $\mathrm{I} h$ in liquid penicillin FL-I060containing medium and then transferred to Methocel medium containing penicillin FL-1060. Pictures were taken $(a) \mathrm{I} \cdot 5 \mathrm{~h},(b) 2.5 \mathrm{~h}$ and $(c) 3.5 \mathrm{~h}$ later. Penicillinase was added and pictures were taken after $(d) \mathrm{I} h$ and $(e) 2 \mathrm{~h}$. The cells in the upper microcolony became spherical after $2.5 \mathrm{~h}$ growth in penicillin $(b)$; after addition of penicillinase they reformed themselves into rod-like cells in the end to end fashion $(d)$.
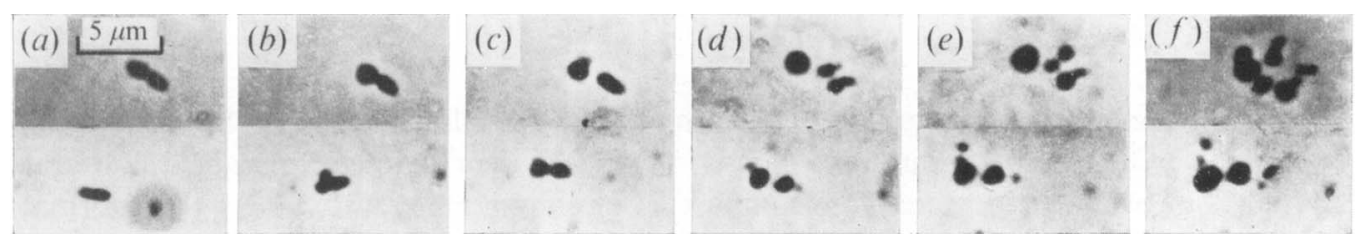

Fig. 5. Morphogenesis of $E$. coli w 7 sphaeroplasts. Cells were grown for $2 \mathrm{~h}$ in liquid DPM-free medium and then transferred to DPM-free Methocel medium. Pictures were taken (a) $0.5 \mathrm{~h}$, (b) $\mathrm{I} .5 \mathrm{~h}$ and (c) $2.5 \mathrm{~h}$ later. DPM was restored to the medium and pictures were taken after $(d) \mathrm{I} h$, (e) $2 \mathrm{~h}$ and $(f) 3 \mathrm{~h}$.

them to Methocel medium containing penicillin FL-I060. These cells were lens-shaped and thus still had ends (Fig. 4a). After being placed in the Methocel medium some of them divided once and produced two spherical daughter cells (Fig. $4 b, c$ ). These were selected for measuring the location of the re-formed ends and were treated with penicillinase (see Methods). The reverting daughters shown in Fig. $4 d$ re-formed themselves into rods aligned end to end. This is the orientation which normal rods have in a chain; thus the spheres in Fig. 4 appear to have formed new ends at the sites where ends would have been if the cells had remained rods. To determine whether this was generally the case, the reversion of 105 pairs of spherical daughter cells was observed: $92 \%$ re-formed themselves into rods aligned end to end. Similar results were obtained with chains of four spheres. Thus the reverting cells usually retained the polarity of the original rods.

Spheres stored at $4{ }^{\circ} \mathrm{C}$ for $24 \mathrm{~h}$ before being allowed to revert also formed their ends at or near the sites of the original ends. Of 23 daughter cells observed, 22 re-formed themselves into rods in the end-to-end fashion. Spheres could also be stored for $24 \mathrm{~h}$ at $37^{\circ} \mathrm{C}$ in growth medium containing chloramphenicol ( $100 \mu \mathrm{g} / \mathrm{ml}$ ) without affecting their capacity to revert to rods after the chloramphenicol was removed. The capacity of the spheres to revert was thus retained for long periods of time even though they were not growing.

The above experiments did not exclude the possibility that it was the contact itself between the cells which was actually determining the site of end formation. This possibility seems unlikely, since lens-shaped cells (still showing polarity) occasionally became spheres without dividing. These formed short chains of rods with the same orientation in the Methocel as the original lens-shaped cells. 


\section{Reversion of the temperature-sensitive morphological mutant LsS I2}

To demonstrate that the above results were neither peculiar to E. coli w7 nor specifically caused by penicillin FL-I060, the experiments were repeated with a temperature-sensitive morphological mutant, Lss 12 , which grows as a sphere at $42{ }^{\circ} \mathrm{C}$ and as a normal rod at $30{ }^{\circ} \mathrm{C}$ (Henning et al. 1972 ). This mutant has an intact sacculus at both temperatures.

When grown at $30^{\circ} \mathrm{C}$ these cells had a diameter of $0.6 \mu \mathrm{m}$ and an average length of $2 \cdot 2 \mu \mathrm{m}$. When transferred to $42{ }^{\circ} \mathrm{C}$ they became spherical after $2 \mathrm{~h}$, with a diameter of $\mathrm{I} \cdot 2 \mu \mathrm{m}$. Upon being returned to $30{ }^{\circ} \mathrm{C}$ they reverted to rods, albeit somewhat slowly; after $\mathrm{I} 3 \mathrm{~h}$ they regained the dimensions of the original rods. The reverting cells showed the same retention of polarity as the pencillin FL-I060-treated cells; of 50 pairs tested, $84 \%$ re-formed chains of rods orientated end to end.

The morphogenesis of spheres with an intact sacculus was very different from that of the sphaeroplasts described by Lederberg (1956). Since our results were obtained using a different solid medium and other strains of $E$. coli, these differences could be explained by assuming that Methocel affected morphogenesis or by assuming that the differences observed were strain-specific. To demonstrate that this was not so, the morphogenesis of E. coli w7 sphaeroplasts was followed in Methocel medium.

\section{Reversion of spheroplasts}

Escherichia coli $\mathrm{w} 7$ is a diaminopimelic acid (DPM) auxotroph. DPM is found only in the sacculus; when these cells are starved of DPM under osmotic protection (12\%,w/v, sucrose) they become sphaeroplasts (Lederberg \& St Clair, 1958; McQuillen, I958; Schwarz \& Leutgeb, 1971). The reversion of sphaeroplasts was initiated by restoring DPM to the medium; the spheres enlarged, but, unlike penicillin FL-I060-treated cells, they remained spherical (Fig. 5). The growth of 124 sphaeroplasts was followed in Methocel medium for $8 \mathrm{~h}$ : I08 were still spherical, 12 had lysed, and three appeared to have reverted to rods. The spheres occasionally formed rod-shaped outgrowths, and rods were often produced from these outgrowths. These rods usually grew and divided normally; the different fate of the spheres and rods shows that it is not sufficient to follow the reversion of a cell population in liquid medium.

Though the spheres could not reshape themselves into rods, it was possible that their growth was not random. If the rod-shaped outgrowths were being formed at specific sites on the surface of the spheres, such as the sites of the original ends, then one could conclude that the cells had retained the polarity of the original rods. Therefore, the location of the outgrowths on the sphaeroplasts was determined. Figure 6 shows that the outgrowths were not formed preferentially at the sites of the original ends but apparently at random around the cell, suggesting that the sphaeroplasts had lost the polarity of the original rods.

It should be noted that the sphaeroplast growth medium contained $12 \%$ sucrose and 0.I M- $\mathrm{MgSO}_{4}$, whereas the penicillin FL-I060 medium did not. These two compounds did not, however, affect the rod-sphere-rod morphogenesis of penicillin FL-I06o-treated cells.

\section{DISCUSSION}

The present studies show that spherical $E$. coli have the capacity to reshape themselves into rods. The morphogenetic capacity of these cells showed three characteristics which imply that within the cell (possibly within the envelope) there exists some kind of stable 


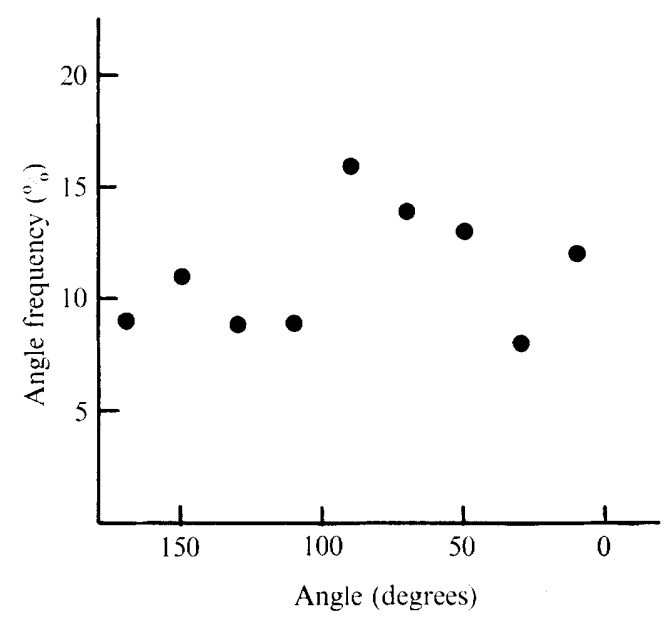

Fig. 6. Location of rod-shaped outgrowths on reverting sphaeroplasts. Cells were grown for $2 \mathrm{~h}$ in liquid DPM-free medium and then transferred to DPM-free Methocel medium as described in Fig. 5. Most of the cells divided once in the Methocel medium before becoming sphaeroplasts. The contact point between the two sister cells was assumed to be the site of one of the original ends of each cell and was defined as $0^{\circ} ; 180^{\circ}$ was assumed to be the site of the other end. DPM was added to the medium and the site of formation of outgrowths on these cells was determined. The formation of 127 outgrowths was observed.

order directing morphogenesis: (i) they retained the potential to revert to rods for long periods of time; (ii) they preserved their polarity and re-formed their ends at (or near) the sites of the original cell poles; (iii) when reverting to rods, they were able to reshape their envelope over most (if not all) of its surface.

Sphaeroplasts did not have these capacities. Escherichia coli $\mathrm{w} 7$ sphaeroplasts synthesize a new (spherical) sacculus within 20 to $30 \mathrm{~min}$ of DPM being restored to the medium (Schwarz \& Leutgeb, I97I); therefore it is not the lack of the sacculus which prevented them from reshaping themselves into rods. Loss of the original sacculus appears to have resulted, either directly or indirectly, in loss of the organization within the cell which enables it to revert to a rod and to retain its polarity. Thus these observations suggest that the sacculus plays a role in the morphogenesis of the cell in addition to its well-known role in maintaining cell shape (Weidel \& Pelzer, 1964). One can only speculate about the nature of this role: within the original sacculus itself there may be specific regions which determine where the ends will be formed during sphere-rod morphogenesis. One other possibility is that the morphogenetic apparatus of $E$. coli is part of a protein matrix within the envelope as suggested by Henning, Rehn \& Hoehn (I973), and that this matrix must be stabilized and held in place by the sacculus.

We thank Dr H. Frank for the electron micrograph in Fig. 2.

\section{REFERENCES}

Greenwood, D. \& O'Grady, F. (I973). FL-IO60: a new beta-lactam antibiotic with novel properties. Journal of Clinical Pathology 26, I-6.

Goss, W. A., DeITZ, W. H. \& Cook, T. M. (1964). Mechanism of action of nalidixic acid on Escherichia coli. Journal of Bacteriology 88, I I $12-\mathrm{I}_{\text {I }}$.

Henning, U., Rehn, K., Braun, V., Höhn, B. \& Schwarz, U. (1972). Cell envelope and shape of Escherichia coli KI2. Properties of a temperature-sensitive rod mutant. European Journal of Biochemistry 26, 570-586. 
Henning, U., Rehn, K. \& Hoehn, B. (1973). Cell envelope and shape of Escherichia coli K I2. Proceedings of the National Academy of Sciences of the United States of America 70, 2033-2036.

Kellenberger, E. \& Arber, W. (I957). Electron microscopical studies of phage multiplication. I. A method for quantitative analysis of particle suspensions. Virology $3,245^{-255}$.

Lederberg, J. (1956). Bacterial protoplasts induced by penicillin. Proceedings of the National Academy of Sciences of the United States of America 42, 574-577.

Lederberg, J. \& St Clatr, J. (1958). Protoplasts and L-type growth of Escherichia coli. Journal of Bacteriology $75,143-160$.

LeUtGeb, W. \& WeIDEL, W. (1963). Über ein in Coli-Zellwandpräparaten zurückgehaltenes Glykogen. Zeitschrift für Naturforschung $\mathbf{1 8 b}$, 1060-1062.

Lin, E. C. C., Hirota, Y. \& JACOB, F. (197I). On the process of cellular division in Escherichia coli. VI. Use of a Methocel-autoradiographic method for the study of cellular division in Escherichia coli. Journal of Bacteriology 108, 375-385.

LUND, F. \& Tybring, L. (1972). 6 $\beta$-amidinopenicillanic acids - a new group of antibiotics. Nature New Biology 236, I35-137.

MCQUillen, K. (1958). Bacterial 'protoplasts': effects of diaminopimelic acid deprival and penicillin addition compared in Escherichia coli. Biochimica et biophysica acta 27, 4I0-4I I.

PARK, J. T. \& BURMAN, L. (1973). FL-I060: a new penicillin with a unique mode of action. Biochemical and Biophysical Research Communications 51, 863-868.

Ryter, A., Hirota, Y. \& Schwarz, U. (I973). Process of cellular division in Escherichia coli. Growth pattern of $E$. coli murein. Journal of Molecular Biology 78, 185-195.

SchWARZ, U. \& LeUTGEB, W. (I97I). Morphogenetic aspects of murein structure and biosynthesis. Journal of Bacteriology 106, 588-595.

Strominger, J. L., Blumberg, P. M., Suginaka, H., Umbreit, J. \& Wickus, G. G. (i97I). How penicillin kills bacteria: progress and problems. Proceedings of the Royal Society of London Br79, 369-383.

Vogel, H. J. \& Bonner, D. M. (I956). Acetylornithinase of Escherichia coli: partial purification and some properties. Journal of Biological Chemistry 218, 97-106.

Weidel, W. \& Pelzer, H. (I964). Bagshaped macromolecules - a new outlook on bacterial cell walls. In Advances in Enzymology, vol. 26, pp. 193-232. Edited by F. F. Nord. New York: Interscience Publishers. 